\title{
CFRP 積層材に対する時間依存非弾性変形のモデリング†
}

\author{
金川 靖* 村上澄 男* \\ 藤 井敏 彦** 溝 辺卓 也 ${ }^{* * *}$

\section{Modeling of Time-Dependent Inelastic Deformation of CFRP Laminates}

\author{
by
Yasushi Kanagawa ${ }^{*}$, Sumio Murakami ${ }^{*}$, Toshihiko FujII ${ }^{*}$
and Takuya MrzobE***

\begin{abstract}
A constitutive model for describing the inelastic deformation of unidirectional and symmetric angle-ply CFRP (Carbon Fiber Reinforced Plastics) laminates is developed. The kinematic hardening creep flow law of Malinin and Khadjinsky and the evolution equation of Armstrong and Frederick are extended to describe the creep deformation of anisotropic materials. In order to express anisotropic hardening, back stress taking account of anisotropic inelastic strain sensitivity is incorporated into the creep constitutive equation. Then, the resulting model is applied to analyze the time-dependent inelastic deformation of symmetric angle-ply laminates. Comparison between the prediction and the experimental observation shows that the present model can describe well the time-dependent inelastic behavior under different loadings.
\end{abstract}

Key words : CFRP laminate, Time dependent inelastic behavior, Creep constitutive equation, Creep potential, Anisotropy, Kinematic hardening

\section{1 緒言}

近年, 複合材料が, 輸送機器などの一次構造材料とし て用いられることが多くなり，厳しい環境下での材料の 力学的挙動の研究が必要とされている. 特に繊維強化複 合材料が繊維方向から偏った方向，あるいは繊維に垂直 方向に垂直応力やせん断応力を受ける場合には, 顕著な 非弾性変形が生じる。また, この非弾性変形にはひずみ 速度依存性が存在する。

このため, 纎維強化複合材料の非弾性挙動を記述する 目的で，これまでいくつかの粘塑性理論が提案されてい る. 例えばMathinson, Pindera ならびに Herakovich $ら^{1)}$ は, Valanis $5^{2), 3)}$ の内部時間理論を炭素繊維強化複合材 料 (CFRP) の単層板と斜交対称積層板に適用した。 た, Yoon と Sun ${ }^{4)} は$, Sun-Chen $5^{5)}$ の 1 パラメータ有効 応力により, CFRP に対して超過応力モデルを提案し, Bodner-Partom モデル ${ }^{6)}$ と記述精度の比較を行なった. しかし，これらのいずれの研究も，単軸比例負荷につい てだけ検討しており，より一般的な荷重条件への適用， または斜交対称積層材への適用について研究は数少ない.

繊維強化高分子複合材料における非弾性変形の機構 は，主に樹脂マトリックスの变形挙動に支配され，転位 の移動に伴って進展する金属の塑性流れとは構造的に大 きく異なっている．架橋構造を持つ分子鎖により形成さ れる熱硬化性樹脂では，材料は荷重下で分子鎖のからみ 合いを保ちながら伸展し, 同時に部分的な再配列が行わ
れる.このため，このような樹脂は金属材料のような明 確な降伏点を持たず，非弾性変形後も分子の完全な再配

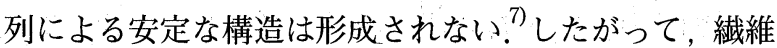
強化高分子材料の非弾性変形を記述するには，通常の塑 性理論, あるいは粘塑性理論ではなく, 変形硬化クリー プ理論を適用することが有効であると思われる.

本研究では, 繊維強化高分子複合材料の巨視的な非弾 性挙動を記述するのに，移動硬化クリープ変形に対する Malinin-Khadjinsky ${ }^{8)}$ の理論を異方性材料に拡張して，新 しい粘性流れ構成式を展開する，続いて，定式化した構 成式を各種配向角を持つ一方向強化 CFRP に適用し， 実験結果の記述を試み，その精度について検討する。ま た，完全接着を仮定する古典積層理論にこの粘性構成式 を組み込み, 様々な荷重状態下での斜交対称積層材の時 間依存非弾性挙動についても考察する.

\section{2 試験片および実験装置}

試験片には，プリプレグ（東レ P3052.12，炭素繊維 T300，沉用エポキシ \#2500）を 8 層積層したFig.1のような 薄肉円管（内径 $15 \mathrm{~mm}, 1$ 層の厚さ $0.125 \mathrm{~mm}$, 標線間距離 $40 \mathrm{~mm}$ ）を用いた。繊維配向角は $11.25^{\circ}, 22.5^{\circ}, 45^{\circ}, 67.5^{\circ}$, $90^{\circ}$ の一方向積層と, $\pm 22.5^{\circ}, \pm 45^{\circ}$ の斜交対称積層である. 実験には電気一油圧サーボ式・軸力ーねじり複合試験機 （島津製作所製 サーボパルサーEHF-EB10/TB1-20L 型） を使用し，ひずみの測定には，軸方向に対してはクリップ ゲージ（MTS 製，MODEL 632.11C-20）を，ねじり方向に

$\dagger \quad$ 原稿受理 平成 8 年 9 月 5 日 Received Sep. 5, 1996

* 正 会 員 名古屋大学工学部機械工学科 T464-01 名古屋市千種区不老町, Dept. of Mech. Eng., Nagoya Univ., Chikusa-ku, Nagoya, 464-01

**ダイハツ工業(株) †563 池田市ダイハツ町, DAIHATSU MOTOR CO. LTD., Daihatsu-cho, Ikeda, 563

*** 名古屋大学大学院 †464-01 名古屋市千種区不老町, Graduate Student, Nagoya Univ. Chikusa-ku, Nagoya, 464-01 


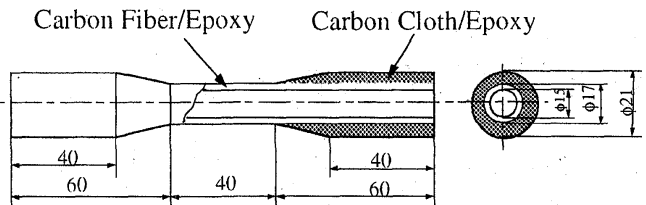

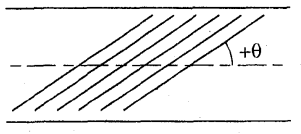

(a) Unidirectional laminate.

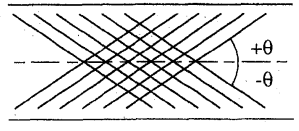

(b) Angle-ply laminate.
Fig. 1. Specimen geometry.

対しては大ひずみゲージ（共和電業製，KFE-5-120-C1）を 用いた。 なお，すべての試験は室温 $21^{\circ} \mathrm{C}$ ので行なった。

\section{3 異方粘性構成式}

\section{$3 \cdot 1$ 座標系}

各種配向角を持つ円管試験片に対し，Fig. 2 に示すよ うに，試験片軸座標系 $(\mathrm{x}, \mathrm{y}, \mathrm{z})$ ，䋊維軸座標系 $(1,2$, 3）の 2 つの座標系を考える。:はじに，一方向積層材 の変形挙動を繊維軸座標系において考察する.

\section{3 - 2 異方粘性材料に対する Malinin-Khadjinsky の理論の拡張}

本論文の対象とする CFRP 積層材の変形は大きくない ので, 以下の理論では微小変形を仮定し, 応力とひずみ はすべて Cauchy 応力と Cauchy ひずみとする.

多軸応力下における時間依存非弾性変形を定式化する にあたり，以下の仮定を設ける。

(1) 材料の粘性変形は体積変化を伴わない.

（2）材料の粘性変形は静水圧に影響を受けない.

(3) 材料は直交異方性である.

(4) 引張りと圧縮の変形挙動は等しい.

材料の全ひずみ $\varepsilon_{i j}$ は, 弾性ひずみ $\varepsilon_{i j}^{e}$ と粘性ひずみ $\varepsilon_{i j}^{v}$ の和で表されるとする。すなわち

$$
\varepsilon_{i j}=\varepsilon_{i j}^{e}+\varepsilon_{i j}^{v}
$$

ここで, 材料の弾性挙動は, 直交異方性に対する一般 化 Hooke 則に従うものとする.

先に述べたように高分子材料の非弾性変形は時間とと もに進行するが，その分子構造は安定な配列を持たない。 このため, 多軸応力下でのこのような変形硬化粘性挙動 を記述するのに, Malinin と Khadjinsky の移動硬化ク リープ理論 ${ }^{8)}$ を直交異方性材料に拡張する。はじめに,

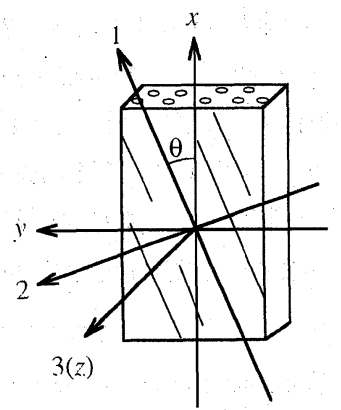

Fig. 2. Coodinate system.
応力空間に打ける等クリープポテンシャル面 $g\left(\sigma_{i j}\right)=$ const と流れ則を仮定すると, 粘性ひずみ速度 $\dot{\varepsilon}_{i j}^{\nu}$ は次式 で表わされる.

$$
\dot{\varepsilon}_{i j}^{v}=\Lambda \frac{\partial g}{\partial \sigma_{i j}}
$$

ここで， $\Lambda$ は応力および負荷経路に依存する正值のスカ ラー関数である。一般の異方性材料に対し，このポテン シャルは次のように書ける.

$$
g\left(\xi_{i j}\right)^{2}=C_{i j k l} \xi_{i j} \xi_{k l}
$$

ここで， $C_{i j k l}$ は 4 階の異方性テンソルであり，また $\xi_{i j}$ は 次式で与えられる有効応力である.

$$
\xi_{i j}=s_{i j}-\alpha_{i j}
$$

上式中の $s_{i j}$ は偏差応力であり, $\alpha_{i j}$ は背応力（Back stress）と呼ばれ，6 次元偏差応力空間における等クリ ープポテンシャル面の中心を表す. 式 (3) の異方性テン ソル $C_{i j k l}$ は，直交異方性材料の場合，Hill の塑性ポテン シャル を採用することにより，次のように求めることが できる。

$$
\begin{aligned}
& C_{1111}=S(G+H), \quad C_{2222}=S(H+F) \\
& C_{3333}=S(F+G), \quad C_{1122}=C_{2211}=-S H \\
& C_{2233}=C_{3322}=-S F, \quad C_{1133}=C_{3311}=-S G \\
& C_{1212}=C_{2121}=S N, \quad C_{2323}=C_{3232}=S L \\
& C_{1313}=C_{3131}=S M
\end{aligned}
$$

ここで, $F, G, H, L, M, N$ は異方性を表現する定数 であり，また $S$ は $S=3 /[2(F+G+H)]$ で与えられる. 式 (3) の具体的な形は, 次のようになる.

$$
\begin{gathered}
g\left(\xi_{i j}\right)=\sqrt{\frac{3}{2(F+G+H)}}\left\{F\left(\xi_{22}-\xi_{33}\right)^{2}+G\left(\xi_{33}-\xi_{11}\right)^{2}\right. \\
\left.+H\left(\xi_{11}-\xi_{22}\right)^{2}+2 L \xi_{23}^{2}+2 M \xi_{31}^{2}+2 N \xi_{12}^{2}\right\}^{1 / 2} \\
\text { 一方, この材料の有効粘性仕事率は } \\
\dot{W}^{v}=\xi_{i j} \dot{\varepsilon}_{i j}^{v}=\xi_{i j} \frac{\partial g}{\partial \sigma_{i j}} \Lambda
\end{gathered}
$$

と表わされる，また連合流れ則によれば，相当応力は式 (3)により，次式のように定義できる.

$$
(\bar{\sigma})^{2}=g\left(\xi_{i j}\right)^{2}=C_{i j k l} \xi_{i j} \xi_{k l}=\frac{3}{2} C_{i j k l}^{\prime} \xi_{i j} \xi_{k l}
$$

このとき, 式 (5) に示す $C_{i j k l}$ の対称性により $\left(\partial \mathrm{g} / \partial \sigma_{i j}\right)$ $\xi_{i j}=g$ が成り立つ. したがって有効粘性仕事率の等価性 により, $\dot{W}^{v}=\bar{\sigma} \overline{\dot{\varepsilon}}^{v}$ を満たす相当粘性ひずみ速度 $\overline{\dot{\varepsilon}}^{v}$ は次 式のように定義できる。

$$
\dot{W}^{v}=g \Lambda=\bar{\sigma} \overline{\dot{\varepsilon}}^{v}
$$

この式から $\Lambda$ を求めると, 式 (2) は次のように書ける。

$$
\dot{\varepsilon}_{i j}^{v}=\overline{\dot{\varepsilon}}^{v} \frac{\partial g}{\partial \sigma_{i j}}
$$

この式の具体的な形は次式で表わされる.

$$
\left.\begin{array}{l}
\dot{\varepsilon}_{11}^{v}=\frac{3}{2(F+G+H)} \overline{\dot{\varepsilon}}^{v} \frac{G\left(\xi_{11}-\xi_{33}\right)+H\left(\xi_{11}-\xi_{22}\right)}{\bar{\sigma}} \\
\dot{\varepsilon}_{22}^{v}=\frac{3}{2(F+G+H)} \overline{\dot{\varepsilon}}^{v} \frac{F\left(\xi_{22}-\xi_{33}\right)+H\left(\xi_{22}-\xi_{11}\right)}{\bar{\sigma}} \\
\dot{\varepsilon}_{33}^{v}=\frac{3}{2(F+G+H)} \overline{\dot{\varepsilon}}^{v} \frac{G\left(\xi_{33}-\xi_{11}\right)+H\left(\xi_{33}-\xi_{22}\right)}{\bar{\sigma}} \\
\dot{\varepsilon}_{12}^{v}=\frac{3}{2(F+G+H)} \overline{\dot{\varepsilon}}^{v} \frac{N \xi_{12}}{\bar{\sigma}}
\end{array}\right\}
$$


ただし，せん断応力は $\sigma_{12}$ だけを非零とした. さらに， 相当粘性ひずみ速度は, 相当応力および有効応力を粘性 ひずみ速度の成分で表すことにより，次のように書ける。

$$
\begin{aligned}
\overline{\dot{\varepsilon}}^{v} & =\sqrt{\frac{2(F+G+H)}{3}}\left\{F\left(\frac{G \dot{\varepsilon}_{22}^{v}-H \dot{\varepsilon}_{33}^{v}}{F G+G H+H F}\right)^{2}\right. \\
& \left.+G\left(\frac{H \dot{\varepsilon}_{33}^{v}-F \dot{\varepsilon}_{11}^{v}}{F G+G H+H F}\right)^{2}+H\left(\frac{F \dot{\varepsilon}_{11}^{v}-G \dot{\varepsilon}_{22}^{v}}{F G+G H+H F}\right)^{2}+2 \frac{\left(\dot{\varepsilon}_{12}^{v}\right)^{2}}{N}\right\}^{1 / 2}
\end{aligned}
$$

つぎに, 式 (2) 中の関数 $\Lambda$ の具体的な形を求める. 単 軸一定応力下での材料の粘性変形が Norton 則 ${ }^{10)}$ に従 い, また, 多軸応力状態に対しては同一の関係が相当応 力と相当ひずみの間に成り立つものとすると, 関数 $\Lambda$ は 相当応力のべき関数によって次のように与えられる.

$$
\Lambda=\overline{\dot{\varepsilon}}^{v}=\left(\frac{\bar{\sigma}}{K}\right)^{n}
$$

\section{$3 \cdot 3$ 背応力の発展式}

等方性材料の相当粘性ひずみ速度は, 次式のように書 ける。

$$
\left(\overline{\dot{\varepsilon}}^{v}\right)^{2}=\frac{2}{3} \dot{\varepsilon}_{i j}^{v} \dot{\varepsilon}_{i j}^{v}
$$

一方, 異方性材料の相当粘性ひずみ速度は, 式 (8) で 定義した相当応力と同様に，次のように表示できる.

$$
\begin{gathered}
\left(\overline{\dot{\varepsilon}}^{v}\right)^{2}=\frac{2}{3} A_{i j k l} \dot{\varepsilon}_{i j}^{v} \dot{\varepsilon}_{k l}^{v}=\frac{2}{3} B_{i j k l} \dot{\varepsilon}_{k l}^{v} B_{i j m n} \dot{\varepsilon}_{m n}^{v}=\frac{2}{3} \dot{\varepsilon}_{i j}^{\prime v} \dot{\varepsilon}_{i j}^{\prime v} \\
\dot{\varepsilon}_{i j}^{\prime v}=B_{i j k l} \dot{\varepsilon}_{k l}^{v}
\end{gathered}
$$

式 (14) と式 (15a) を比較すれば，等方材料における粘性 ひずみ速度 $\dot{\varepsilon}_{i j}^{\prime v}$ の効果は, 異方性材料においては式 (15b)の $\dot{\varepsilon}_{i j}^{\prime v}$ と等価であることが分かる.

ここで, 式 (12) と式 (15a) を比較することにより 4 階 の異方性テンソル行列 $B_{i j k l}$ の非零成分を求めると, 次の ようになる。

$$
\begin{gathered}
B_{1111}=(P F)^{\frac{1}{2}}, B_{2222}=(P G)^{\frac{1}{2}}, B_{3333}=(P H)^{\frac{1}{2}} \\
B_{1212}=B_{1221}=B_{2112}=B_{2121}=\left(\frac{F+G+H}{4 N}\right)^{\frac{1}{2}} \\
\text { ただし }, P=(F+G+H) /(F G+G H+H F) \text { である. }
\end{gathered}
$$

つぎに, 式 (4) 中の背応力の発展式を求める. 背応力 の発展は粘性ひずみによってもたらされるとし, 線形部 分と非線形成分の 2 つの成分から構成されるとする.

$$
\dot{\alpha}_{i j}=\dot{\alpha}_{i j}^{(1)}+\dot{\alpha}_{i j}^{(2)}
$$

非線形部分については, Armstrong-Frederick ${ }^{11)}$ の移動硬 化変数を採用する.これらの背応力の発展式の異方性材 料への拡張は，等方性材料に拈ける発展式中のひずみ速 度 $\dot{\varepsilon}_{i j}^{v}$ を, 式 (15b) で定義したひずみ速度 $\dot{\varepsilon}_{i j}^{v}$ に置き換 えることによって可能となり，次式を得る。

$$
\begin{gathered}
\dot{\alpha}_{i j}^{(1)}=Q_{1} \dot{\varepsilon}_{i j}^{\prime v}=Q_{1} B_{i j k l} \dot{\varepsilon}_{k l}^{v} \\
\dot{\alpha}_{i j}^{(2)}=b\left(Q_{2} \dot{\varepsilon}_{i j}^{\prime v}-\alpha_{i j}^{(2)} \overline{\dot{\varepsilon}}^{v}\right)=b\left(Q_{2} B_{i j k l} \dot{\varepsilon}_{k l}^{v}-\alpha_{i j}^{(2)} \overline{\dot{\varepsilon}}^{v}\right)
\end{gathered}
$$

なお，本構成式は $3 F=3 G=3 H=L=M=N$ とおくと， 等方性材料の問題に帰着する.

\section{$3 \cdot 4$ 材料定数の同定}

以上で導いた異方粘性構成式中の材料定数を，実験に
よって同定する方法を検討する。はじめに，繊維に直交 方向の横等方性より $H=G$ となり，さらに平面応力状態 を仮定すれば, 決定すべきパラメータは $F, G, N$ の 3 つとなる。これらのパラメータは, 式 (8) より, 一定ひ

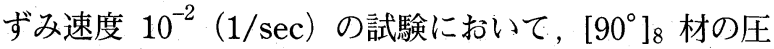
縮, $\left[90^{\circ}\right]_{8}$ 材のねじり, $\left[45^{\circ}\right]_{8}$ 材の引張りの 3 つの相当 応力 - 相当ひずみ関係が一致するように決定した.

つづいて, 粘性構成式中の材料定数 $K, n, Q_{1}, Q_{2}$, $b$ を決定する.これらの值は, 最も単純なひずみ状態と して, $\left[90^{\circ}\right]_{8}$ 材に対する一定ひずみ速度単純ねじり試験 を行なって求めることができる，この条件下で式 (13)を 変形すると, 次式を得る。

$$
\hat{\alpha}_{12}=\sqrt{\frac{3 N}{F+2 G}} \sigma_{12}-K\left(\overline{\dot{\varepsilon}}^{v}\right)^{\frac{1}{n}}
$$

$\hat{\alpha}_{12}=\sqrt{3 N /(F+2 G)} \cdot \alpha_{12}, \overline{\dot{\varepsilon}}^{v}=\sqrt{4(F+2 G) / 3 N} \cdot \dot{\varepsilon}_{12}^{v} \quad(20 \mathrm{~b})$ 式 (13) の材料定数 $K$ と $n$ は，上式を 3 種類の一定ひず み速度試験結果に当てはめ, 各場合の背応力の発展が同 一の曲線で表現できるように定めることができる. Fig. 3 は，この結果を示している。

次に，純ねじり負荷状態において式 (18), 式 (19)を積 分し, 両者の和をとると次式を得る.

$$
\hat{\alpha}_{12}=\sqrt{\frac{9 N}{4(F+2 G)}}\left\{Q_{1} \bar{\varepsilon}^{v}+Q_{2}\left[1-\exp \left(-b \bar{\varepsilon}^{v}\right)\right]\right\}(21)
$$

上式を用い Fig. 3 中の実測值を近似することで， $Q_{1}$ $Q_{2}, b$ を決定することができる.

以上により求めた材料定数を以下に示す.

$$
\left.\begin{array}{rl}
F=1.56 \times 10^{-4} & G=2.02 \times 10^{-11} \\
N=9.36 \times 10^{-4} & K=2.61 \times 10^{2}(\mathrm{MPa}) \\
n=1.09 \times 10 & Q_{1}=3.12 \times 10^{3}(\mathrm{MPa}) \\
b=2.09 \times 10^{3} & Q_{2}=3.39 \times 10(\mathrm{MPa})
\end{array}\right\}
$$

\section{4 一方向積層材に対する各種試験結果}

のシミュレーション

前節で提案したクリープ構成式に, 式 (22)の材料定 数を用い, 一方向積層材の一定応力速度負荷下での非弾 性変形に対するシミュレーションを試みる。まず，様々 な配向角を持つ試験片に対し，応力速度が $0.05,5$, $100(\mathrm{MPa} / \mathrm{sec})$ である単純引張試験を行った. $\left[90^{\circ}\right]_{8}$ 材に関しては, 非線形が顕著である単純圧縮試験を行っ

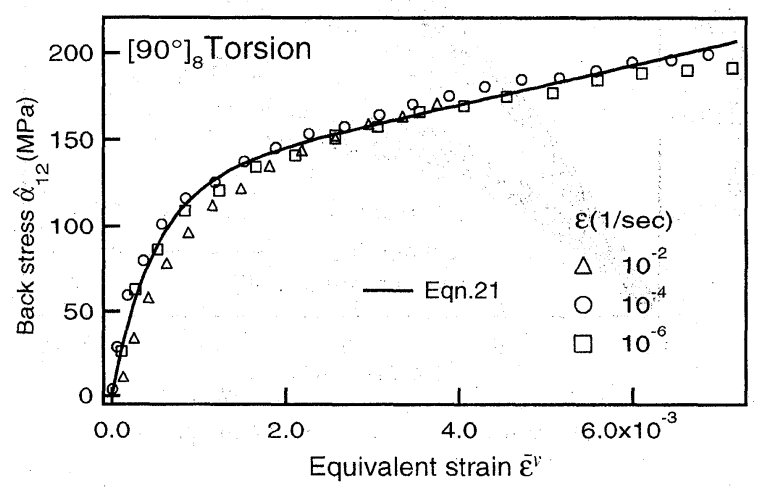

Fig. 3. Evolution of back stress. 
た. 実験結果を計算結果と併せて Fig. 4 (a), Fig. 5 (a), Fig. 6 に示す。なお以下の図中の応力とひずみの実験值 はすべて, 試験片に作用する荷重とその変位から計算し た試験片厚さ中央における值を示す。

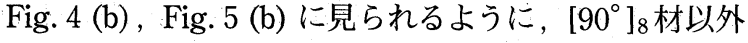
の実験では, 異方性の主軸方向から負荷方向が偏ってい るため, 軸力の作用によって，ねじりひずみが生じる. このねじりひずみの軸応力に対する関係を，各応力ひず み線図に併せて示す。

な打, 応力速度 $100(\mathrm{MPa} / \mathrm{sec})$ の実験に打いては, 他の応力速度での試験と若干傾向が異なっているものが 見られるが，これは，速い応力速度のため，試験機の制 御が追従していないことによるものであると思われる。こ のような多少の実験誤差が認められるものの，いずれの 実験についても，計算結果は繊維配向角による非弾性挙 動の違いと同時に，その応力速度依存性を定量的によく 記述していることが分かる。

\section{5 斜交対称積層材に対する各種試験結果} のシミュレーション

つづいて，一方向積層材に対し 3 章で定式化した構成 式を，斜交対称積層材に適用する。実際の積層材には， わずかながら樹脂りッチな中間層が存在し，層間変形を

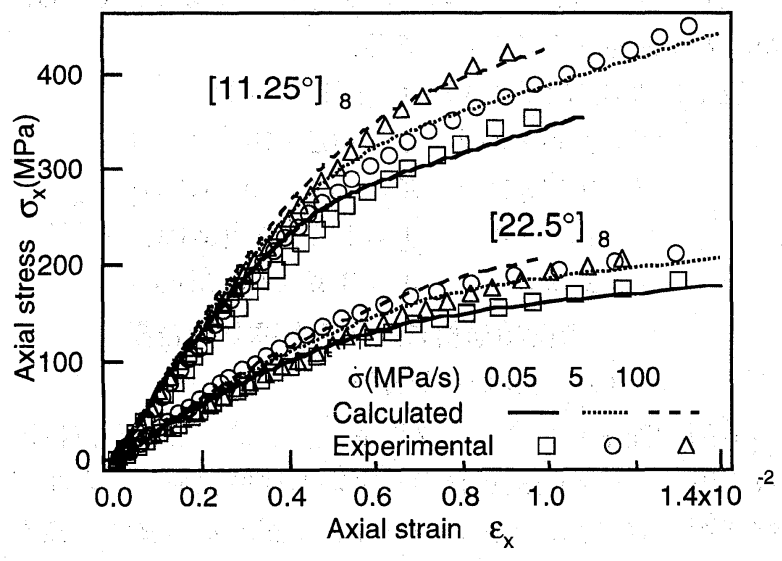

(a) Axial stress versus Axial strain

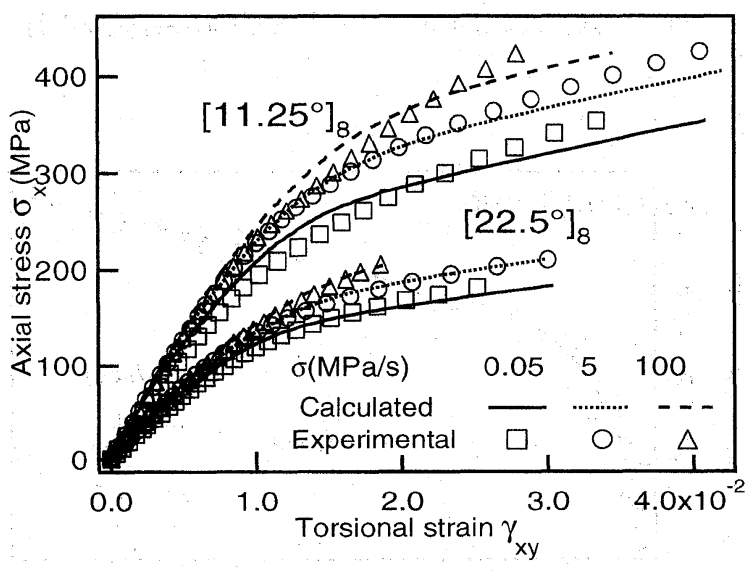

(b) Axial stress versus Torsional strain.

Fig. 4. Stress-strain relations under stress controlled pure tensile loading.

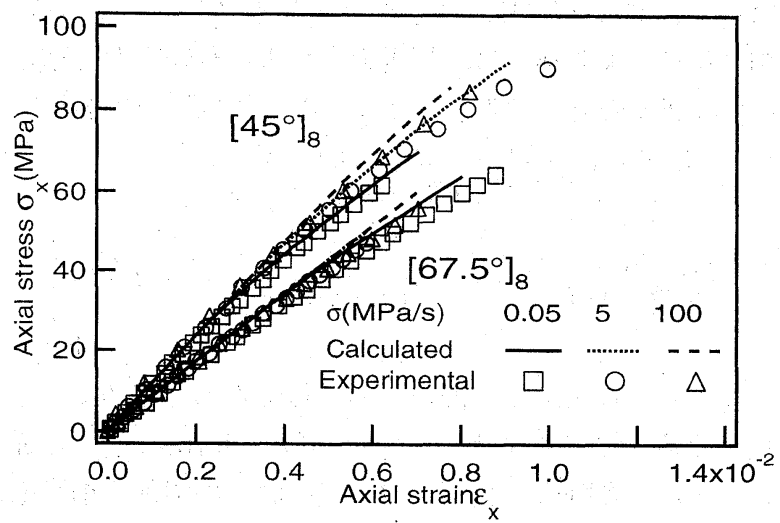

(a) Axial stress versus Axial strain.

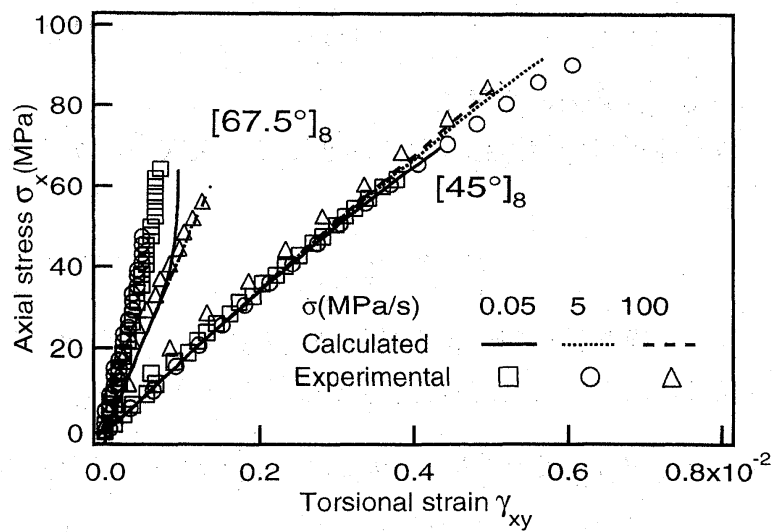

(b) Axial stress versus Torsional strain

Fig. 5. Stress-strain relations under stress controlled pure tensile loading.

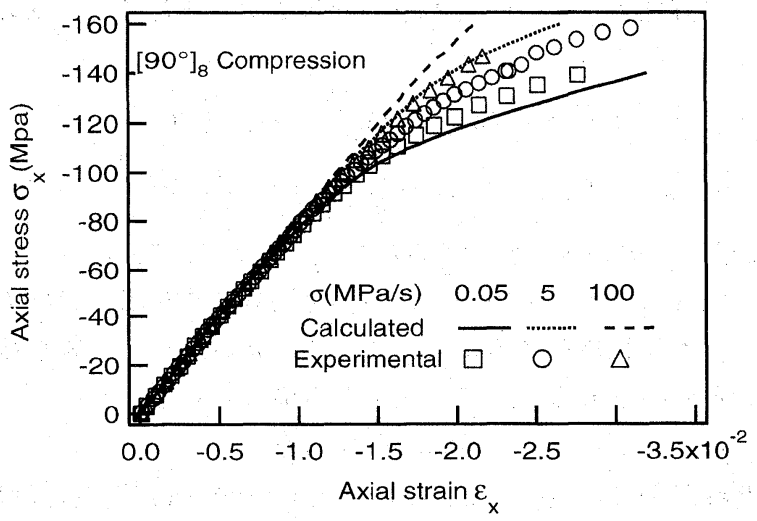

Fig. 6. Stress-strain relations under stress controlled pure compressive loading.

生じる可能性がある。しかし本研究では簡単化のため, 各層の間にひずみの連続性を仮定する古典積層理論に基 ゔき, 以下の手順により斜交対称積層板の応力-ひずみ関 係を求める. $+\theta$ 層と- $\theta$ 層の䋊維軸座標系の各ひずみを 本構成式から計算し, 試験片軸座標系のひずみに変換す る. その際,$+\theta$ 層のひずみと $-\theta$ 層が完全に接着してい ると考え，両層のひずみが一致するように付加応力 $\Delta \sigma$ を数值的に近似解を求めて計算し, 試験片軸座標系の応 
力に付加する.

Fig. 7 (a)，（b) に， [ $\left.\pm 22.5^{\circ}\right]_{4},\left[ \pm 45^{\circ}\right]_{4}$ 積層材に対す る応力速度 $0.05,5,100(\mathrm{MPa} / \mathrm{sec})$ での単軸引張試 験の結果と計算結果を示す.

$\left[ \pm 45^{\circ}\right]_{4}$ の積層材については，計算結果はひずみを小 さく見積もる傾向にある．これは，完全接着を仮定した 積層理論に起因すると考えられる，実際の層間には，わ ずかながら樹脂リッチな層が存在しており，せん断応力 に対するこの層間層の変形により各層にひずみ差が生じ ていると考えられる.

また，その他の要因として損傷の影響が考えられる。

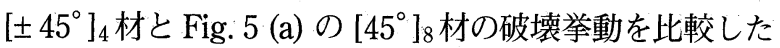
とき, $\left[45^{\circ}\right]_{8}$ 材は局所的な損傷による材料不安定で, 比 較的小さいひずみにおいて破壊しているが， [ $\left.44^{\circ}\right]_{4}$ 材 は強化方向の違う隣り合った層が打互いにひずみを拘束 するため，局所的な損傷が生じても不安定破壊に至らず 連続的に損傷が発展し，そして，それに起因する材料の 軟化を伴いながら変形が進行すると考えられる，以上の ような差異が見られるが, 本構成式, および積層理論は, 材料の非弾性挙動をおおむねよく記述する.

次に, 本研究で用いた構成式および積層理論の, 様々 な荷重状態への適用性を評価するために, 変形の非線形 性が顕著な $\left[ \pm 45^{\circ}\right]_{4}$ 材を用い, クリープ試験, 応力速 度変動試験, 負荷-除荷-再負荷試験を行った。

まず，クリープ試験の実験結果と，それに対する計算 結果を Fig. 8 に示す. 実験では, 最初に応力速度 200 $(\mathrm{MPa} / \mathrm{sec})$ で $70 \mathrm{MPa}$ まで負荷し，そこで荷重を 2 時間 保持し，時間に対するひずみの増加を測定した，図の横 軸は規定の応力に達した時を 0 とした時間，縦軸は弾性 ひずみを除いたクリープひずみである，実験より，この ような比較的小さい応力に扔いても顕著なクリープひず みが生じていることがわかる、計算結果は，このクリー プ挙動をよく記述している。

つづいて, 応力速度変動試験について, 応力速度を $0.05(\mathrm{MPa} / \mathrm{sec})$ から $100(\mathrm{MPa} / \mathrm{sec})$ に階段的に増加 させた試験結果を Fig. 9 (a) に, また逆に応力速度を $100(\mathrm{MPa} / \mathrm{sec})$ から $0.05(\mathrm{MPa} / \mathrm{sec})$ に減少させた結 果を Fig. 9 (b) に示す. ただし罒中の破線は, 応力速度 を一定としたときの, 計算による応力-ひずみ曲線であ る. 応力速度が階段的に変化したとき, 変化後の応力-ひ ずみ関係は, 遷移状態を経た後, 応力速度一定の応力-ひ ずみ関係に一致する．いずれの計算結果も実験值をよく 記述しており, 本構成式はこのような荷重下でも妥当で あると考えられる。

最後に, 本構成式の負荷-除荷-再負荷試験に対する適 用について検討する。この試験では，応力速度を 5 $(\mathrm{MPa} / \mathrm{sec})$ とした。一般に, このような繰返し荷重下 においては, その材料特性は, 疲労損傷によって大きく 影響を受けるが, 疲労開始直後のサイクルにおいては,

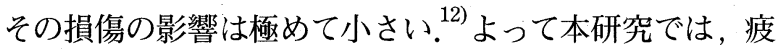
労損傷の影響が無視できる疲労のごく初期の材料の変形 挙動について考察する.

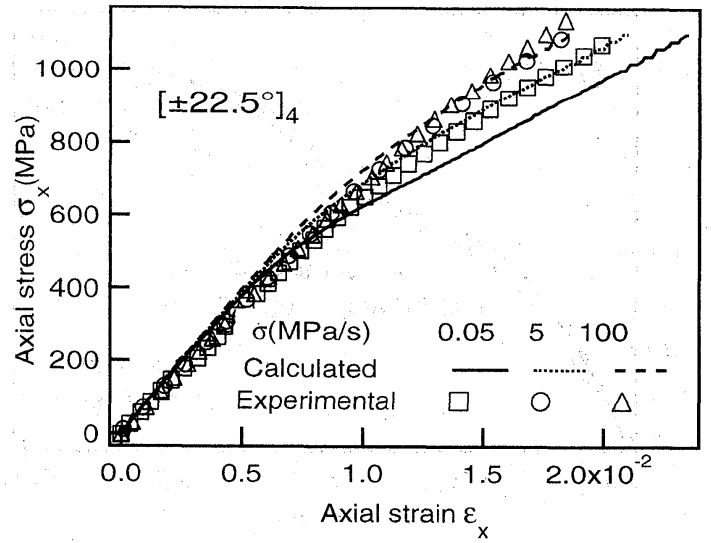

(a) $\left[ \pm 22.5^{\circ}\right]_{4}$ angle-ply laminates.

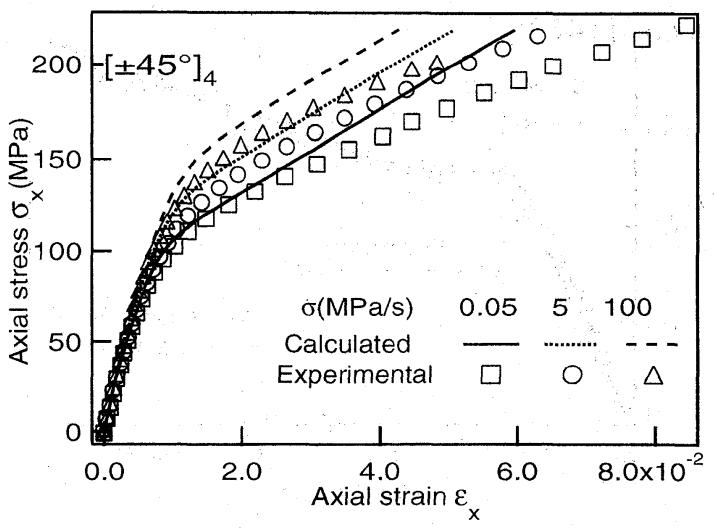

(b) $\left[ \pm 45^{\circ}\right]_{4}$ angle-ply laminates.

Fig. 7. Stress-strain relations of angle-ply laminates under pure tensile loading.

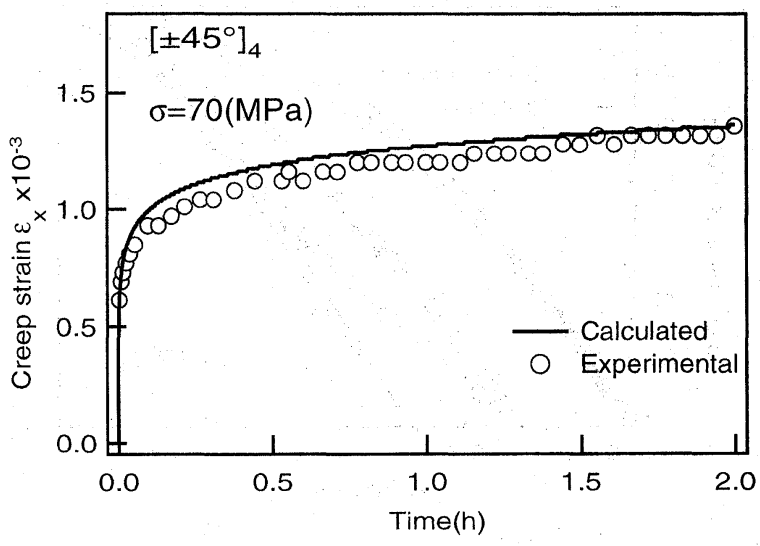

Fig. 8. Creep curve of $\left[ \pm 45^{\circ}\right]_{4}$ angle-ply laminates under constant stress.

実験結果は, Fig. 10 に示すように顕著なヒステリシ スループを描く、計算結果はこの挙動を定性的には表現 しているが，ヒステリシスループを十分には表現できて いない。これは高分子材料に特徵的な擬弾性によるひず み回復の影響と考えられる。本研究で用いた構成式も， ある程度の回復は表現できるが，より正確に回復を記述 するには, 構成式に, 弾性項・粘性項のほか, 新たに擬 弾性項を加える必要があると思われる。 


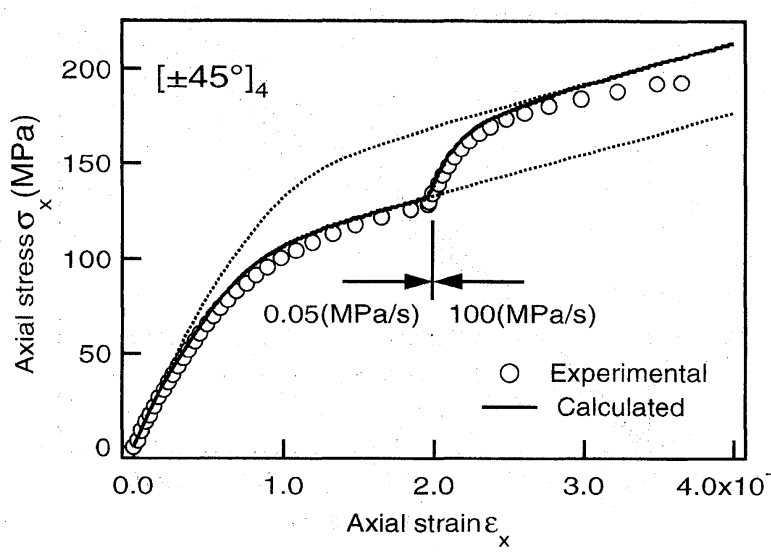

(a) Stepup change in stress rate.

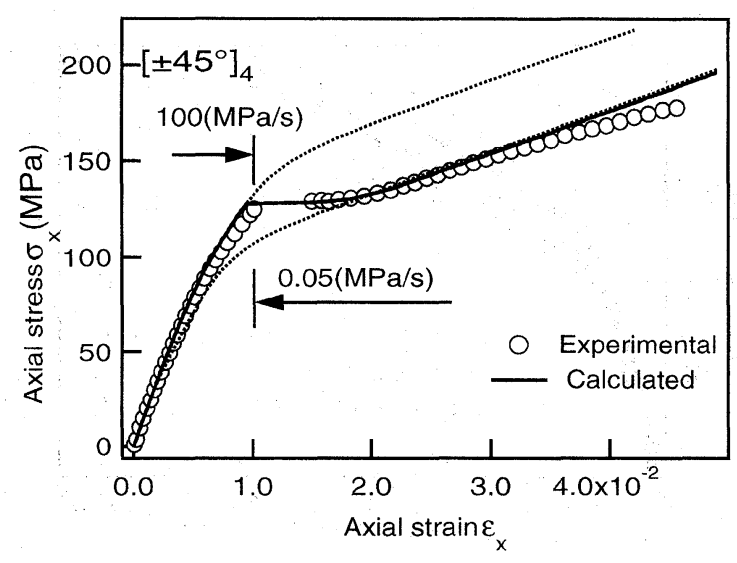

(b) Stepdown change in stress rate.

Fig. 9. Stress-strain relations of $\left[ \pm 45^{\circ}\right]_{4}$ angle-ply laminates under stepwise change in stress rate.

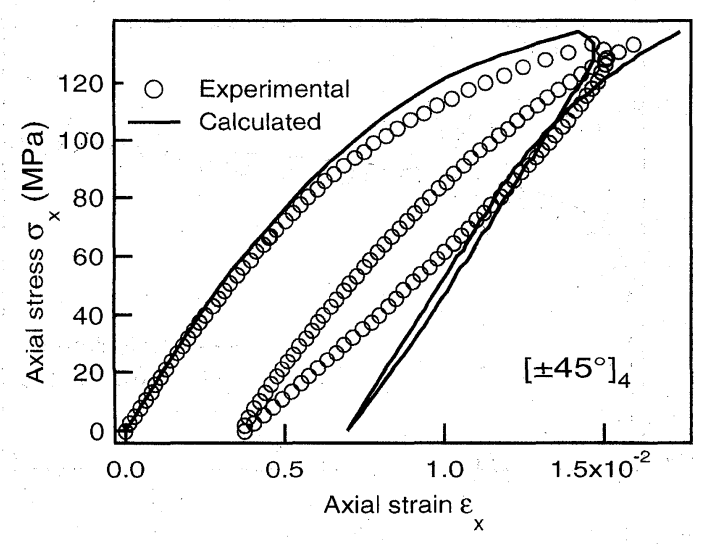

Fig. 10. Stress-strain relations of $\left[ \pm 45^{\circ}\right]_{4}$ angle-ply laminates under loading-unloading-reloading condition.

\section{6 結言}

Malinin-Khadjinsky の移動硬化クリープ理論と Armstrong-Frederick の背応力の発展式を直交異方性材 料に拡張し, CFRP の時間依存非弾性変形構成式を定式 化した。つづいて，この理論を各種配向角を持つ一方向 積層 CFRP に適用し, 一定応力速度下での実験結果の 記述を試み，その精度について検討した。また，完全接 着を仮定する古典積層理論にこの粘性構成式を組み込む ことで, 斜交対称積層材についても考察した. 以上より 次の結論を得た.

（1）提案した構成式により，様々な配向角を持つ一方 向積層円管試験片の; 単純引張一定応力速度試験に対し, その複雑な非弾性挙動およびその時間依存性を, 精度よ く記述することができた。

（2）完全接着に基づく積層理論に，提案した粘性構成 式を組み込み斜交対称積層材に適用した。この結果，層 間の変形挙動，損傷の影響を考虑していないため，比較 的大きいひずみ領域において，実験結果との若干の差が 認められた。しかし，ひずみの小さい範囲では，実験值 を精度よく記述することができた。

(3) 本構成式は, $\left[ \pm 45^{\circ}\right]_{4}$ 材の応力速度変動試験, クリープ試験において，実測值を精度よく記述すること ができるが, 負荷-除荷-再負荷試験の際の, 擬弾性によ る顕著なヒステリシスループは十分に表現できない.今 後，構成式に弾性，粘性に加え，新たに擬弾性の項を付 加する必要があるものと思われる。

\section{参 考 文 献}

1) S. R. Mathison, M. J. Pindera and C. T. Herakovich, Trans. ASME, J. Eng. Mater. Technol., 113, 449 (1991).

2) K. C. Valanis, Arch. Mech., 23, 517 (1971).

3) K. C. Valanis, Arch. Mech, 23, 535 (1971).

4) K. J. Yoon and C. T. Sun, J. Comp. Mat., 25, 1277 (1991).

$5)$ C. T. Sun and J. L. Chen, J. Comp. Mat., 23, 1009 (1989).

6) S. R. Bodner and Y. Partom, Trans. ASME Ser. E, J. appl. Mech., 42, 385 (1975).

7) 牧野内昭武, 北條英典, 塑性と加工, 29, 997 (1988).

8 ) N. N. Malinin and G. M. Khadjinsky, Int. J. Mech. Sci., 14, 235 (1972).

9) R. Hill, "The mathematical theory of plasticity" (1950) The Clarendon Press.

10）日本材料学会編，“固体力学の基礎”（1981）日刊工業新 聞社.

11) P. J. Armstrong and C. O. Frederick, CEBG Report, NO. $\mathrm{RD} / \mathrm{B} / \mathrm{N} 731$ (1966).

12）石田孝明，金川 靖，佐野村幸夫，玉置一雄，日本機械 学会論文集, A-60, 105 (1994). 